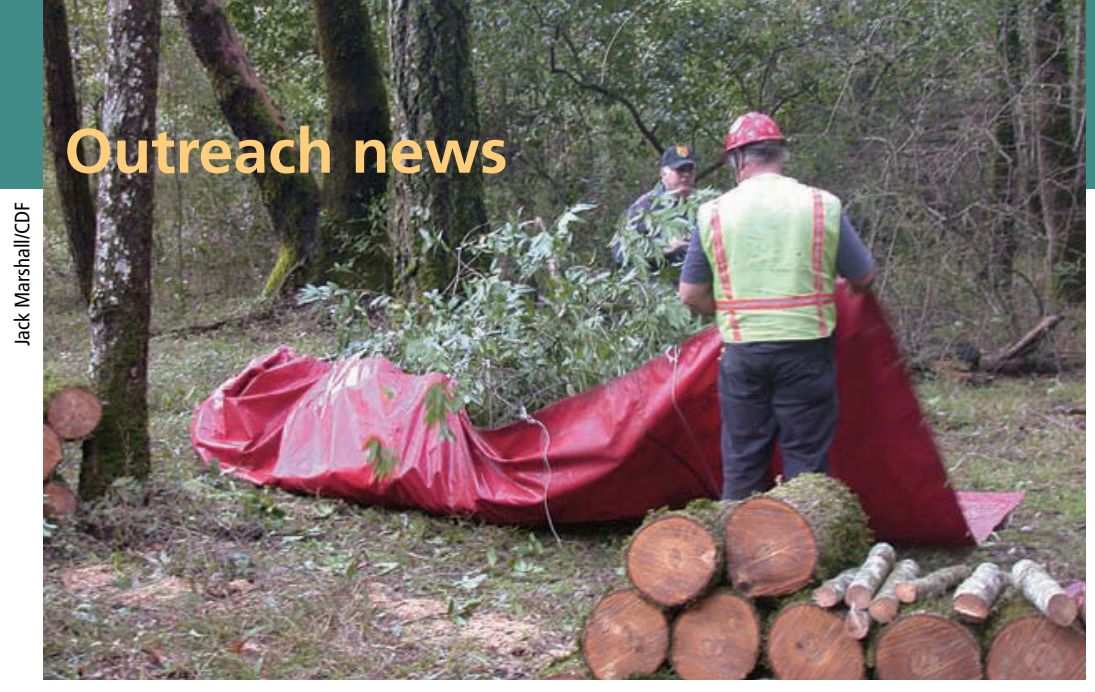

In an effort to slow the spread of $P$. ramorum, UC Cooperative Extension joined Humboldt County and state agencies to remove and dispose of 77 infected California bay laurel trees. Soil, water and plants in the area are being monitored to determine if this procedure was effective in limiting the pathogen's spread.

\section{Survey seeks to improve sudden oak death outreach}

$\mathrm{E}_{\mathrm{s}}^{\mathrm{s}}$ stablished in coastal California counties from Monterey to Humboldt, the pathogen that causes sudden oak death prefers cool, wet climates and is spread by raindrops, infected plant material and people. "That's why it's so important that we get the word out about how to prevent the spread of this dangerous pathogen," says Janice Alexander, sudden oak death outreach coordinator for the California Oak Mortality Task Force (COMTF) and UC Cooperative Extension (UCCE).

Formed in 2000 and supported by state and federal agencies, COMTF is a nonprofit organization devoted to sudden oak death research, management, education and public policy. The organization has about 1,000 members from about 80 groups comprising other nonprofits, public agencies and private interests. Working together, COMTF and UCCE have developed educational resources that include a comprehensive Web site, training sessions and monthly newsletters.

To evaluate and improve sudden oak death education and outreach efforts, COMTF and UCCE Marin County conducted a statewide survey in April 2005. "We wanted to know how well we were reaching our audiences," says COMTF vice-chair Susan Frankel, manager of the U.S. Forest Service Sudden Oak Death Research Program in Albany.

Sudden oak death is caused by Phytophthora ramorum, an oomycete or water mold that resembles a fungus but is actually more closely related to downy mildews and potato blight. First seen in Marin County a decade ago, sudden oak death is now found in wildlands in 14 coastal California counties and one in southwest Oregon. In addition, the pathogen that causes the disease is found in nurseries across the United States and Europe. The disease gets its name from the fact that infected oak canopies can turn brown within weeks, and the trees can ultimately die. P. ramorum infects a variety of host plants that carry and spread the pathogen but are not killed by it, including California bay laurel, coast redwood and common nursery plants such as rhododendrons and camellias.

The outreach survey was posted online for a month and targeted people who are already concerned and knowledgeable about sudden oak death, including nursery professionals, arborists, homeowners, government resource specialists and UCCE Master Gardeners. "Part of the challenge in getting the word out is the diversity of those who need to know," Frankel says.

Overall, the response to the survey was positive. "It validated what we've already done," Alexander says. More than $90 \%$ of the 302 respondents said information about the disease was easily accessible, and the primary source of this information was the COMTF Web site. In addition, the training sessions were useful to nearly all of the $65 \%$ of respondents who had attended them. Moreover, based on what they learned about $P$. ramorum, nearly $90 \%$ of private sector respondents had changed their business practices (by, for example, disinfecting tools and other equipment after working with infected trees) and $80 \%$ also changed their personal practices (by, for example, washing their shoes and car tires when leaving infested areas).

The survey was used to identify further outreach needs. "We got lots of concrete suggestions," Alexander says. "It was like brainstorming with people." The suggestions included providing more information on how to distinguish $P$. ramorum from common look-alike diseases such as root rot and bacterial wetwood, and coordinating outreach efforts with state and local parks in infested areas.

Alexander also wants to increase outreach to nurseries. "The pathogen has a huge economic impact on nurseries because a positive find means destroying all the neighboring plants in the block," she says. So far, nurseries have destroyed 1.6 million plants nationwide due to $P$. ramorum infections.

Controlling the pathogen in nurseries is challenging because it thrives in the shady, moist conditions that are also preferred by the ornamental host plants. Sanitary measures include keeping host plants in smaller blocks and separating them with nonhost plants, making sure water does not drip from above and splash on leaves, and keeping plants on gravel instead of soil, where the pathogen can lie dormant for months.

However, these measures are not foolproof. "Some nurseries have had a hard time eradicating the pathogen and it's a big mystery why," says Alexander. "There's still a lot we don't know about how the disease spreads and establishes."

- Robin Meadows 